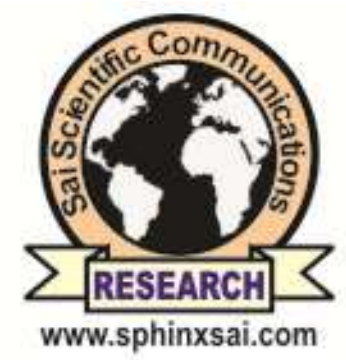

International Journal of PharmTech Research
CODEN (USA): IJPRIF, ISSN: 0974-4304, ISSN(Online): 2455-9563 CODEN (USA): IJPRIF, ISSN: 0974-4304, ISSN(Online): 2455-9563
Vol.12, No.01, pp 63-68, 2019

\title{
Bacteria Pattern Aerobic and Anaerobic From Surface Swab and Tonsillar Core Culture in Patients With Recurrent Tonsillitis
}

\author{
Daniel Ginting ${ }^{1 *}$, Abdul Rachman², Linda Adenin², R Lia Kusumawati ${ }^{3,4}$, \\ Mirzan Hasibuan ${ }^{4}$, Harry Asroel $^{2}$, Yusa Herwanto ${ }^{2}$ \\ ${ }^{1}$ Resident in Department of Otorhinolaryngology-Head and Neck Surgery, \\ Faculty of Medicine, Universitas Sumatera Utara, Medan, 20155, Indonesia; \\ ${ }^{2}$ Department of Otorhinolaryngology-Head and Neck Surgery, Faculty of \\ Medicine, Universitas Sumatera Utara, Medan, 20155, Indonesia; \\ ${ }^{3}$ Department of Microbiology, Faculty of Medicine, University of Sumatera Utara, \\ JI. Universitas No. 1 Kampus USU Medan 20155, Indonesia; \\ ${ }^{4}$ University of Sumatera Utara Hostpital, JI. Dr. T. Mansyur No. 66 Kampus USU \\ Medan 20155, Indonesia.
}

\begin{abstract}
Backgrounds: Tonsillitis is the most common disease in otorhinolaryngology both acute and chronic, especially in children. Recurrent tonsillitis is a chronic inflammatory process in the palatine tonsils. Several studies have shown differences in pathogenic flora on surface and tonsillar core. This also causes an increase failure of eradicating germs in acute tonsillitis. Therefore, it falls into chronic stage. Identifying the bacterial organism in acute tonsillitis will guide appropriate antibiotic therapy that can revolutionize the management of chronic tonsillitis.Objectives: To determine the bacteria pattern from surface and tonsillar core in patients with recurrent tonsillitis. Methods: The research is a descriptive with cross sectional study. The sample of the study was patients with recurrent tonsillitis who underwent tonsillectomy surgery at Adam Malik General Hospital Medan and several satellite hospitals in Medan that met the inclusion criterias. Results:This study was attended by 33 recurrent tonsillitis subjects with more male(66,7\%) and most of them below 20 years $(66.7 \%)$. The most type of aerobic bacteria from surface and tonsillar core swabs was Staphylococcus aureus. Antibiotics that are still sensitive to Staphylococcus aureus in tonsillar core swabs are Gentamycin, Tigecycline, Clindamycin, and Inezolid. Antibiotics that are still sensitive to Staphylococcus aureus on surface smears are Tigecycline, Vancomycin, and Erythromycin. The bacteria form surface did not present bacteria from tonsillar core. The most anaerobic bacteria found on both ofthe surface and tonsillar core were Bacteroides fragilis. Conclusions:The swab cultures taken from the tonsillar surface may not always reveal the real pathogen of the tonsils. In addition, the estimated probability of tonsillar bacteriology by surface swabs varies with the type of the pathogen.
\end{abstract}

Key words : bacteria pattern, swab, surface, tonsillar core, recurrent tonsillitis.

Daniel Ginting et al /International Journal of PharmTech Research, 2019,12(1): 63-68.

DOI: http://dx.doi.org/10.20902/IJPTR.2019.120109 


\section{Introduction}

Tonsillitis is the most common disease in otorhinolaryngology both acute and chronic, especially in children. ${ }^{1}$ In the process of recurrent tonsillitis, the mucosal epithelium of lymphoid tissue often experiences injury, so that the healing process is replaced by scar tissue which causes the crypts to be wide. Predisposing factors for the onset of chronic tonsillitis are chronic stimulation of cigarettes, several types of food, poor oral hygiene, influence of weather, physical fatigue and often caused by inadequate treatment of acute tonsillitis resulting in recurrent inflammation of the mucosal epithelium. ${ }^{2}$ Surface swabof tonsil is often used as a guide to identify thebacterial organisms and treatment options in acute and chronic tonsillitis. Several studies have shown differences in pathogenic flora on surface and tonsillar core. This can explain the increasing failure rate in the eradication of the infection in acute tonsillitis, especially penicillin group of antibiotics so that they leads to chronic stage. Identifying the bacterial organism in acute tonsillitis will guide appropriate antibiotic therapy that can revolutionize the management of chronic tonsillitis.,

\section{Material and Methods}

This research is a descriptive with a cross sectional study. The samples were patients with recurrent tonsillitis who underwent tonsillectomy surgery at Adam Malik General Hospital Medan and several satellite hospitals in Medan that met the inclusion criterias. Those are chronic tonsillitis patients with acute exacerbation episodes at least three times per year, undergoing tonsillectomy surgery and not receiving antibiotic therapy at least 48 hours before surgery, and willing to be included in the study with signing informed consents. The samples were obtained by using a non probability sampling technique with a consecutive sampling approach. Tonsil surface swab was done by using sterile sticky cotton. Tonsil that had been removed by tonsillectomy procedure will be dipped into povidone-iodine within 30 seconds. Then, rinsed with sterile $\mathrm{NaCl}$ solution. The tonsil was placed on a sterile surface and sliced into two parts using a sterile scalpel. Next, put it into the amies tube and close tightly before placed into the coolerbox and sent to the laboratory for examination. If a positive culture is identified using the Vitek 2 Compact tool.

\section{Results}

This study was attended by 33 recurrent tonsillitis subjects with 22 male $(66,7 \%)$ and 11 female $(33,3 \%)$. The most subjects were below 20 years as many as 22 patients $(66.7 \%)$, followed by $20-29$ years as many as 8 patients $(24.2 \%)$ and above 30 years as many as 3 sufferers $(9.1 \%)$. Based on Table 1, the most type of aerobic bacteria from tonsillar core swabswas Staphylococcus aureus which was found in 10 subjects (30.3\%). Antibiotics that are still sensitive to Staphylococcus aureus in tonsillar core swabs based on Table 2 are Gentamycin and Tigecycline in 8 subjects (80\%) as well as Clindamycin and Inezolid in 7 subjects (70\%). The most type of bacteria (Table 3) from the surface aerobic smear samples was Staphylococcus aureus (33.3\%). Antibiotics that are still sensitive to Staphylococcus aureus (Table 4) on surface smears are Tigecycline and Vancomycin (90.9\%) and Erythromycin (72.7\%). Based on Table 5, the comparison between surface and tonsillar cores was $14(42 \%)$ different pathogenscases, whereas those with the same pathogen found only 11 cases $(33 \%)$. From Table 6, the most anaerobic bacteria found were Bacteroides fragilis both on the surface $(50 \%)$ and in the tonsillar core (30\%).

Table 1. Results of Aerobic Bacterial Types Examination based on Sampling Location from Tonsillar Core Swab

\begin{tabular}{|l|l|l|}
\hline Bacterial Types & Frequency & \% \\
\hline Staphylococcus aureus & 10 & 30.3 \\
\hline Klebsiella pneumoniae & 4 & 12.1 \\
\hline Streptococcus pneumoniae & 3 & 9.1 \\
\hline Streptococcus salivarius & 3 & 9.1 \\
\hline Rothia mucilaginosa & 2 & 6.1 \\
\hline Acinetobacter haemolyticus & 1 & 3 \\
\hline Enterobacter cloacae & 1 & 3 \\
\hline Enterococcus avium & 1 & 3 \\
\hline Enterococcus faecalis & 1 & 3 \\
\hline
\end{tabular}




\begin{tabular}{|l|l|l|}
\hline Pseudomonas flourescens & 1 & 3 \\
\hline Pseudomonas stutzeri & 1 & 3 \\
\hline Staphylococcus epidermidis & 1 & 3 \\
\hline Streptococcus agalactiae & 1 & 3 \\
\hline Streptococcus cristatus & 1 & 3 \\
\hline Streptococcus pharyngis & 1 & 3 \\
\hline T o t a l & 33 & 100 \\
\hline
\end{tabular}

Table 2. Antibiotics Sensitivity and Resistance Test Results on Staphylococcus aureus from Tonsillar Core Swabs Examination

\begin{tabular}{|l|l|}
\hline \multirow{2}{*}{ Antibiotics } & Staphylococcus aureus $\mathbf{( n = 1 0 )}$ \\
\cline { 2 - 2 } & S (\%) \\
\hline Gentamycin & $8(80)$ \\
\hline Tigecycline & $8(80)$ \\
\hline Clindamycin & $7(70)$ \\
\hline Linezolid & $7(70)$ \\
\hline Eritromycin & $6(60)$ \\
\hline Nitroforantoin & $6(60)$ \\
\hline Tetracycline & $6(60)$ \\
\hline Vancomycin & $5(50)$ \\
\hline Cotrimoxazole & $4(40)$ \\
\hline Cefoxitin & $4(40)$ \\
\hline Moxifloxacin & $4(40)$ \\
\hline Ciprofloxacin & $3(30)$ \\
\hline Oxacilin & $3(30)$ \\
\hline Ampicillin & $2(20)$ \\
\hline Benzylpenicilin & $2(20)$ \\
\hline
\end{tabular}

Table 3. Results of Aerobic Bacterial TypesExamination based on Sampling Locations from Surface Swabs

\begin{tabular}{|l|l|l|}
\hline Bacterial Types & Frequency & \% \\
\hline Staphylococcus aureus & 11 & 33.3 \\
\hline Klebsiella pneumoniae & 6 & 18.2 \\
\hline Streptococcus salivarius & 3 & 9.1 \\
\hline Pseudomonas aeruginosa & 2 & 6.1 \\
\hline Streptococcus agalactiae & 2 & 6.1 \\
\hline Streptococcus cristatus & 2 & 6.1 \\
\hline Aeromonas hydrophilla & 1 & 3.0 \\
\hline Enterobacter cloacae & 1 & 3.0 \\
\hline Enterococcus faecalis & 1 & 3.0 \\
\hline Kocuria kristinae & 1 & 3.0 \\
\hline Rothia mucilaginosa & 1 & 3.0 \\
\hline $\begin{array}{l}\text { Staphyloccocus coagulase } \\
\text { negatif }\end{array}$ & 1 & 3.0 \\
\hline Streptococcus pneumoniae & 1 & 3.0 \\
\hline Total & 33 & 100.0 \\
\hline
\end{tabular}


Tabel 4.Antibiotics Sensitivity and Resistance Test Results on Staphylococcus aureus from Surface Swabs Examination

\begin{tabular}{|l|l|}
\hline \multirow{2}{*}{ Antibiotics } & $\begin{array}{l}\text { Staphylococcus aureus } \\
(\mathbf{n = 1 1})\end{array}$ \\
\cline { 2 - 2 } & $\mathbf{S}(\mathbf{\%})$ \\
\hline Tigecycline & $10(90,9)$ \\
\hline Vancomycin & $10(90,9)$ \\
\hline Eritromycin & $8(72,7)$ \\
\hline Cefoxitin & $7(63,6)$ \\
\hline Linezolid & $7(63,6)$ \\
\hline Nitroforantoin & $7(63,6)$ \\
\hline Cotrimoxazole & $5(45,5)$ \\
\hline Tetracycline & $5(45,5)$ \\
\hline Benzylpenicilin & $4(36,4)$ \\
\hline Oxacilin & $4(36,4)$ \\
\hline Ciprofloxacin & $3(27,3)$ \\
\hline Levofloxacin & $3(27,3)$ \\
\hline Moxifloxacin & $3(27,3)$ \\
\hline Ampicillin & $2(18,2)$ \\
\hline Gentamycin & $1(9,1)$ \\
\hline
\end{tabular}

Table 5. Comparison Aerobic Bacteria from Surface Swab and Tonsillar Core Culture

\begin{tabular}{|l|l|l|}
\hline Tonsillar Core Culture & Surface Swab Culture & Total(\%) \\
\hline Normal flora & Pathogen & $2(6 \%)$ \\
\hline Pathogen & Pathogen (same) & $11(33 \%)$ \\
\hline Pathogen & Pathogen (different) & $14(42 \%)$ \\
\hline Pathogen & Normal flora & $3(9 \%)$ \\
\hline Normal flora & Normal flora & $3(9 \%)$ \\
\hline & & $33(100 \%)$ \\
\hline
\end{tabular}

Tabel 6. Examination Result of Anaerobic Bacterial Types based on Sampling Locations from Surface Swab and Tonsillar Core

\begin{tabular}{|l|l|l|}
\hline Bacteria Types & $\begin{array}{l}\text { Frequency of Tonsillar } \\
\text { Core(\%) }\end{array}$ & $\begin{array}{l}\text { Freqeuncy of } \\
\text { Surface Swab(\%) }\end{array}$ \\
\hline Bacteroides fragilis & $3(30 \%)$ & $4(50 \%)$ \\
\hline Peptostreptococcus sp. & $3(30 \%)$ & $3(30 \%)$ \\
\hline Actinomyces sp. & $2(20 \%)$ & 0 \\
\hline Fusobacterium sp. & $1(10 \%)$ & $1(10 \%)$ \\
\hline Veillonella sp. & $1(10 \%)$ & 0 \\
\hline
\end{tabular}

\section{Discussion}

This study involved of 33 recurrent tonsillitis subjects with the most common group of age was below 20 years $(66,7 \%)$ and males were more than females. This was consistent with the research of Kurien and Stanis (2000), that number of age group below 20 years was the most. ${ }^{5}$ Chronic tonsillitis often occurs at a young age because they tends to be exposed to dust, pollution, extreme weather, and unhygienic water. ${ }^{6}$ Percentage of males were the most because they more often involved with outdoor activities. ${ }^{7}$ Based on Table 1 , the most common type of aerobic bacteria from tonsillar core was Staphylococcus aureus (30.3\%). This is consistent with the Al-Roosan's study (2008) who found that the most commonlytonsillar core culture was Staphylococcus aureus. ${ }^{3}$ Yildirim et al (2003) reported that Staphylococcus aureus is an important pathogen in 
nosocomial infections and cause of bacteremia that often occurs in postoperative patients. ${ }^{8}$ Based on Table 2 , antibiotics that are still sensitive to Staphylococcus aureus in tonsillar core swabs are Gentamycin and Tigecycline (80\%) as well as Clindamycin and Inezolid (70\%). According to Stein et al (2003) and Elsherif (2011) the rate of antibiotic resistance can be reduced by using antibiotics wisely, using empirical antibiotic therapy and drug combinations from different groups. ${ }^{9,4}$ Based on Table 3, the most type of aerobic bacteria from surface swab was Staphylococcus aureus (33.3\%). This is in accordance with Elsherif's study(2011), that Staphylococcus aureus is the most common pathogen in surface and tonsillar core. ${ }^{4}$ This is not in accordance with Kurien's study(2000), that streptococcal beta haemolytic is the most common bacteria in tonsillar surface and core. ${ }^{5}$ Antibiotics that are still sensitive to Staphylococcus aureus (table 4) on surface swabs are Tigecycline and Vancomycin (90,9\%) as well as Erythromycin (72,7\%). Decreasing the level of resistance can be done by using antibiotics wsely and using empirical therapy as well as various types of drug combinations. ${ }^{10,9}$ Based on Table 5, the different results of surface swab and tonsillar core culture was found as many as 19 cases (57\%), while only 14 cases (43\%) were found in the same culture. This is in accordance with Rekabi's study(2008), the results of different culture were found in 68 cases, while the results of same culture were 52 cases from the total of 120 patients. ${ }^{11}$ According to Al-Hameed (2014), tonsil surface swab has a minor diagnostic value to determine the causative bacterial organismcompared to tonsillar coreculture. ${ }^{12}$ Based on Table 6 , the most anaerobic bacteria was Bacteroides fragilis on the tonsillar surface $(50 \%)$ and tonsillar core (30\%). Khaldikar (2016) also conducted the same study and found the most bacteria were Porphyromonas sp. (22 cases) and Bacteroides fragilis (13 cases). ${ }^{13}$

\section{Conclusion}

From the total of 33 recurrent tonsillitis subjects, number of males were more dominant than females and below 20 years was the largest group of age. The most common type of aerobic bacteria from surface and tonsillar core wasStaphylococcus aureus. Antibiotics that are still sensitive to Staphylococcus aureusfrom tonsillar core are Gentamycin, Tigecycline, Clindamycin, and Inezolid. Antibiotics that are still sensitive to Staphylococcus aureus from suface areTigecycline, Vancomycin, anda Erythromycin. The bacteria form surface did not present bacteria from tonsillar core. The most common anaerobic bacteria found on the surface and tonsillar core was Bacteroides fragilis.

\section{References}

1. Jeong, J. et al.Bacteriologic Comparison of Tonsil Core in Recurrent Tonsillitis and Tonsillar Hypertrophy. The Laryngoscope Lippincott Williams \& Wilkins. 2007: 2146-51.

2. Iskandar N, Soepardi E, Bashiruddin J, Restuti R. Buku Ajar Ilmu Kesehatan Telinga Hidung Tenggorokan Kepala dan Leher. Jakarta: Balai Penerbit FKUI. 2007:6.

3. Al-Roosan M, Al-Khotum N, Al-SaidH. Correlation between surface apusan culture and tonsillar core culture in patients with recurrent tonsillitis,Khartoum Medical Journal, Vol. 01. 2008: 01(03).122.

4. Elsherif A, Abdelrahman Y, Abdelazeem M, Elsherbiny N.Discrepancy between tonsillar surface and core culture in children with chronic tonsillitis and incidence of post tonsillectomy bacteraemia,AlAzhar Assiut Medical Journal,2011:9.

5. Kurien, et al., 2000, Throat Swab in the Chronic Tonsilitis: How Reliable and Valid is it?, Singapore Medical Journal, Vol 41(7):324-326.

6. Marwat, et al, 2010, Prevalence of tonsillitis in Khalifa Gul Nawaz \& district headquarter hospital Bannu, Department of Community Medicine Bannu Medicalcollege.

7. Mattila, S, et al., 2001, Causes of tonsillar disease and frequency of tonsillectomy operations, Archives of Otolaryngology-Head \& Neck Surgery,vol. 127, pp. 37-44. doi:10.1001/archotol.127.1.37.

8. Yildirim et al. Bacteraemia during tonsillectomy. J. Laryngology and Otology, 2003:117: 619-23. doi:10.1258/002221503768199951.

9. Stein C, Weber D, Kelly M. Using Hospital antibiogram data to assess regional resistance to antibiotics, Emerging infectious disease. 2003:8(2).211-6. doi:10.3201/eid0902.020123.

10. Farid M., Al Saffar S., 2000, In vitro activity of antibiotics against Gram negative bacilli isolated from patients in intensive care and burns units,Egyptian Journal of Medical Microbialogy, (9): 4: 685-691. 
11. Rekabi H, Khosravi A, Ahmadi K, Kardouni M, The microbiologic comparison of the surface and deep tissue tonsillar cultures in patients underwent tonsillectomy,Journal of Medical Sciences, 2008:8:32528. doi:10.3923/jms.2008.325.328.

12. Al-Hameed F, Al-Ansary A, Rukaia N, Muna M. Comparative study in Bacteriological findings between the surface and the core of chronic infected Tonsils. Department of Otolarynglogy-Head \&Neck Surgery,College of medicine,Thi-qar university. 2014.

13. Khaldikar, M., Ankle, N., Anaerobic Bacteriological Microbiota in Surface and Core of Tonsils in Chronic Tonsilitis,Journal of Clinical and Diagnostic Research, 2016:10(11).MC01-MC03.

$* * * * *$ 